\section{Protean evolution}

Jerry A. Coyne

Macroevolutionary Dynamics: Specles, Niches, \& Adaptive Peaks. By Niles Eldredge. McGraw-Hill: 1989. Pp.226. Hbk \$28.95; pbk \$14.95.

EvOlutionaRy biologists have found it hard to wrestle with the theory of punctuated equilibrium, for, like Proteus, it changes form when firmly grasped. Having gradually abandoned many of the key concepts, its proponents still insist that it is a revolutionary explanation of macroevolution, the large-scale changes in the types and numbers of organisms during the history of life.

Punctuated equilibrium's newest incarnation, described in Macroevolutionary Dynamics, is missing further parts. Gone are the ideas that evolutionary stasis is caused by ontogenetic resistance to change, that key evolutionary innovations begin as maladaptive features fixed by genetic drift, that macromutations play a large role in evolution, and that evolutionary trends result from species selection. Although the new, truncated theory is barely recognizable as punctuated equilibrium, Eldredge implies that it has not changed much since the controversial original version of 1972 . But those who have followed this controversy will be astonished at Eldredge's revisionism, including the assertion that he and Stephen Gould always "remained neo-Darwinian gradualists in the sense that the brief periods of relatively rapid change involved intergradational, rather than saltational, phenotypic transformation, presumably under the control of natural selection" (p.66).

This short volume, apparently written for those with a professional interest in evolution, describes the two remaining tenets of punctuated equilibrium. The first is the familiar idea that species change very little over most of their evolutionary history. This stasis is no longer attributed to developmental homoeostasis, but to a combination of behavioural habitat selection (organisms seek out familiar niches when the environment changes, therefore experiencing no new selection) and disruptive natural selection (different populations adapt to different local environments, and the 'average' environment among populations of a species does not change).

These ideas may correctly explain unchanging species, but they certainly do not predict them. Not many plants, for example, can avoid unpleasant environments. Even in animals, habitat selection causes stasis only when a familiar habitat can be found in a changing world, but this must often be impossible (why else is there extinction?). Disruptive selection is even less plausible, for the argument assumes that there is never any change in the 'average' habitat among populations, and that directional selection cannot apply over a species' entire range. The former idea seems unreasonable, and the latter clearly wrong. It is easy to think of geographically widespread forms of natural selection, including the introduction of new parasites or diseases, selection for crypsis, sexual selection and mutations that increase fecundity.

The second tenet - and the only nondarwinian one - is that large changes of morphology are allowed only by speciation. There are, of course, good darwinian reasons for expecting an association between morphological change and reproductive isolation. Natural and sexual selection can cause reproductive isolation as a byproduct, the classical explanation of adaptive radiations. Also, as Douglas Futuyma has noted, when a population becomes reproductively isolated it may keep adaptations that would normally be diluted away by gene flow from the rest of the species. This would likewise cause an association between speciation and morphological change. But Eldredge proposes something more radical: that reproductive isolation actually triggers adaptive change in geographically isolated populations.

Reproductive isolation is, however, a property of pairs of species that is seen only when they become sympatric, and it is difficult to see how its evolution in allopatry could somehow cause a species to acquire new adaptations. Indeed, Eldredge himself is hard pressed to come up with an explanation, suggesting only that new species could evolve rapidly by competing with their relatives. But such character displacement will affect only adaptations that reduce competition, and fails to account for many other features, especially those distinguishing related but geographically isolated species (for example, flightlessness in island birds). Because Eldredge has largely abandoned the only other non-darwinian part of punctuated equilibrium (species selection), the weakness of this argument brings down the last barrier separating his theory from neo-darwinism.

Unless Macroevolutionary Dynamics was intended as yet another revision of punctuated equilibrium, the reasons for the book's existence are unclear. Most of the material has been widely discussed elsewhere, the only novel element being a long and rather abstract discussion of the role of communities and ecosystems in evolution. The extensive philosophizing, as well as the dearth of biological examples supporting Eldredge's arguments, suggest that punctuated equilibrium is gradually losing its connection with the real world of organisms.

Jerry A. Coyne is in the Department of Ecology and Evolution, University of Chicago, $1103 \mathrm{E}$. 57th Street, Chicago, Illinois 60637, USA.

\section{Mischance for Mr Darwin}

\section{A.J. Cain}

The Correspondence of Charles Darwin, Volume 4 1847-1850. Edited by Frederick Burkhardt and Sydney Smith. Cambridge University Press: 1989. Pp. 711. £32.50, \$32.50.

THE fourth volume of Charles Darwin's correspondence covers a period of four years in which, although he was intensely active, comparatively little went on of obvious excitement for the reader. Very little of this volume will give material for sensationalist literary writers (although I can recommend Darwin's use of chloroform in childbirth and his heroic remedies for toothache - did they simply kill the tooth?). This was one of those periods of heavy slogging work, with slow progress, and doubts developing about earlier ideas, that make up so much of any working scientist's life, and are usually characterized afterwards (sometimes rightly) as periods of consolidation. He had already sketched out his ideas on evolution, and published his Journal and his geological volumes. In the present period he published his contribution to the Admiralty Manual of Scientific Enquiry (1849).

All the usual mischances of life were bothering him in the usual way. Parcels of priceless specimens on loan to him went astray, guests had to be instructed on how to get to Down, references were required for friends for various jobs (he refused flatly to write one for someone he didn't know), there were difficulties over shares and farm rents and Emma Darwin's trust fund, his artist was (he thought) inexcusably dilatory, the printers of the Admiralty Manual made a hash of his contribution. But in addition his health was often very poor, and much time was spent on treatments which made only temporary improvements. His wife's pregnancies were sometimes difficult, scarlet fever attacked the family, one child had a convulsive fit, and his deeply respected father died. No wonder that he reported to Hooker on one occasion that "all things [have] gone on badly".

All this time he was keeping up his vast correspondence - with nurserymen and amateur breeders about variation, hybridity and inheritance, with other naturalists on effects of acclimation, taxonomic variation, geographical distribution, coral reefs, transported boulders (erratic blocks), the maximum inclination at which a lava stream could solidify, craters of volcanoes, raised sea beaches, salt from salinas, rock cleavage and foliation, ripple-marks on the sea bed at various depths, and especially the so- 
[Down]

\section{My dear $\mathbf{M}^{\mathrm{r}}$ Innes}

I am extremely sorry to hear of your toothache.-You must not put, I think more than one drop of Chloroform on the tooth..-3 I send Tincture of Arnica ${ }^{4}$ which smarts the skin (deadly Poison) to put outside. - $\mathrm{M}^{\mathrm{rs}}$ Darwin finds hot fomentations do best.- Many find cold water applications best.-

I have found two or three drops of Alum \& S $w^{t}$ Spirits of Nitres (in bottle with a label) sometimes do my teeth great good. I was not in when your note came

Yours | C. Darwin

I send my bottles which you can return afterwards

I send Creosote, ${ }^{6}$ some find a drop of this do much good

Kill or cure - Darwin's sympathetic note to John Innes, Vicar of Down in Kent where the Darwin family lived from 1842, written in January 1848. (Reproduced from The Correspondence of Charles Darwin, Vol. 4; footnotes not included.)

called roads of Glen Roy. These are parallel lines on the hillsides of Glen Roy, near Ben Nevis, Scotland, marking successive levels of a former lake dammed up by a glacier.

But his principal activity was his work on barnacles, which, however, was moving into a more humdrum phase. His great discoveries were already made, and it was now a matter of completing his species descriptions, settling his taxonomic ranks and (most wearisome of all) determining his specific and generic nomenclature. This led to an interesting exchange of letters with Hugh Strickland over the principle of priority in nomenclature. Darwin thought it would favour bad and hasty work. He was in fact right. But Strickland had the better grasp of the art of making rules.

Michael Ghiselin, I believe, was the first to point out the importance of Darwin's work on barnacles, in his Triumph of the Darwinian Method (University of California Press, 1969). Up until then it had usually been ignored as something of an aberration, largely (I suspect) because historians and philosophers were incapable of understanding it. The reader is ably assisted in the present volume by a 22-page essay, Darwin's Study of the Cirripedia (it is Appendix II), which oddly does not refer to Ghiselin and has no author's name. Both the essay and the correspondence support Ghiselin's thesis of the importance of the work in confirming and testing Darwin's ideas on evolution. In particular, the extraordinary intermediates between the hermaphrodite condition and that with separate sexes served to strengthen previous ideas of his on the corresponding evolutionary modification of hermaphrodite flowers.

One wishes desperately for similar aids to understanding the controversies over the roads of Glen Roy, erratic blocks and volcanic craters. Darwin's correspondence with Lyell and Milne over Glen Roy is necessarily highly allusive to what they knew or had published, and correspondingly highly cryptic to a modern reader who has not been over the actual ground in the company of a Quaternary geologist. Clearly, it is impossible for the editors to explain all these topics as well as the barnacles - one can only be grateful that the essay on them was included. The volumes of correspondence are the essential basis for starting on such explanations, which must be a collective effort independent of this series.

Moreover, the volumes of correspondence will be invaluable for assembling a series of real-life case-histories of what can go wrong in research. Failures of

\section{Range finder}

\section{Henry Gee}

Dinosaur Plots \& Other Intrigues in Natural HIstory. By Leonard Krishtalka. Morrow, New York: 1989. Pp.316. $\$ 17.95$.

THE West, apparently, "is where men are men and the plumbing is outside". It is also full of field palaeontologists like Leonard Krishtalka, who, when not actually digging things up in Wyoming (where the bar in the Big Horn Hotel in Arminto "seats four and leans five"), writes for the "Missing Links" column in the Carnegie Institute's bimonthly Carnegie Magazine. Twenty-five of his more off-beat contributions have mosied their way into this book, but Krishtalka's editors have made them wipe their boots first.

This is an irreverent collection of essays, far from the scholarly minutiae of Stephen Jay Gould's "Natural History" column or Carl Sagan's cosmic epics. Isaac Asimov could have written them if he'd been raised in a tin shack in Idaho popular science, yet spiced with the kind of sleeves-rolled-up aphorisms one might expect in the writings of a bonehunting man.

We learn, for example, that the only rather than a sweetshop in Brooklyn - classification (Darwin ignored some of the roads because he thought they were only sheep tracks), correct argument but from too narrow premises (as over dykes and eruptions), facts inadequately ascertained (the actual heights of the roads), or just plain wrong (Goodsir's description of a parasite as the male of the barnacle), inadequate observation for lack of a directing hypothesis (some of Hooker's geological observations in the Himalayas) - almost every practical and theoretical mistake that can occur in research could be illustrated authentically from these topics. A catalogue raisonnée of them would form an admirable manual of admonition for young research workers.

This volume, like its companions, is well produced and edited, and includes massive supporting notes, a concordance of the letters, lists of manuscript annotations, and family trees. Appendix I is a chronology from Darwin's original notebook, recently discovered; Appendix III gives his original observations on his children; and Appendix IV is his original notes of works to be read and works read, now published complete and with its own bibliography (which it needs). An excellent piece of work.

A.J. Cain is Emeritus Professor of Zoology in the University of Liverpool, PO Box 147, Brownlow Street, Liverpool L69 3BX, UK.

spirits worth investigating come in bottles marked 'single malt', and that all the cows in a given field tend to face in the same direction. This last is true at least for the fields along Interstate 80 between Pennsylvania and Wyoming. These states are the twin poles around which Krishtalka's life revolves, because he curates bones in the former but unearths them in the latter. Anecdotes drawn from Krishtalka's personal experience riddle the book, and although they add life to an isolated essay, their cumulative effect in a collection such as this may be cloying for some. Nevertheless, the western view of the domestication of the cow is both entertaining and informative, especially the idea for employing the monolithically orientated cattle as billboards along the highway.

The range of topics is eclectic, not to say eccentric, but is not far from what one might find in an Asimov collection. Intelligent life in the Universe, DNA, fossils (lots of them) and broadsides against creationists, spiritualists and other hangers-on all get a look in. But there the similarities end. Krishtalka's informal style is a world away from The Good Doctor's eastern polish, and when sounding off on things he feels strongly about his is the wry and intimate voice of the saloon bar regular rather than the insistent tone of a soapbox orator. Here is a book to save for the next time you're lonesome on the trail.

Henry Gee is on the editorial staff of Nature. 